\title{
Small and Medium Tourism Enterprises Green Operation Performance Level
}

\author{
Zeenat Begam Yusof', Mansor Ibrahim¹, Mariam Jamaludin², Md Mizanur Rashid ${ }^{3}$ \\ ${ }^{1}$ Kulliyyah of Architecture and Environmental Design, International Islamic University Malaysia, \\ ${ }^{2}$ MJ Architect, Malaysia, \\ ${ }^{3}$ School of Architecture and Built Environment, Deakin University, Australia \\ zeensoni@iium.edu.my,profmansor@iium.edu.my,marja67@gmail.com,mmd.rashid@deakin.edu.au \\ Tel: +600193930350
}

\begin{abstract}
Small and Medium Tourism Enterprises (SMTEs) contribute up to $70 \%$ of world pollution by consuming water, energy and producing solid waste. A similar scenario could be observed in the case of the Malaysian islands. Therefore, it is significant to understand SMITEs green operation performance level. Thus, this research aims to investigate into SMTEs green operation performance levels in the area of energy, freshwater, and solid waste. This research uses quantitative and qualitative methods for data collection. The findings indicate that the SMITEs have low performance in the area of freshwater and have moderate performance in energy and solid waste.
\end{abstract}

Keywords: Green practices; Performance level; Marine Park Islands; SMTEs

eISSN: 2398-42870 2021. The Authors. Published for AMER ABRA cE-Bs by e-International Publishing House, Ltd., UK. This is an open access article under the CC BYNC-ND license (http://creativecommons.org/licenses/by-nc-nd/4.0). Peer-review under responsibility of AMER (Association of Malaysian Environment-Behaviour Researchers), ABRA (Association of Behavioural Researchers on Asians/Africans/Arabians) and CE-Bs (Centre for Environment-Behaviour Studies), Faculty of Architecture, Planning \& Surveying, Universiti Teknologi MARA, Malaysia.

DOI: https://doi.org/10.21834/ebpj.v6i16.2729

\subsection{Introduction}

Small and Medium Tourism Enterprises (SMTEs) is the largest business segment in the hospitality sector and generates up to $60 \%$ of global economic output (Hillary, 2004). SMTEs are recognised as vital contributors to economic development, improving quality of life (Chan \& Hsu, 2016; Mejia, 2019). However, SMTEs are often widely quoted as a sector contributing up to $70 \%$ of all industrial pollution (Hillary, 2004). In France, a survey by ADEME (2007) indicates that SMTEs are accountable for $40-45 \%$ of all industrial air emissions, water consumption, energy consumption, and $60-70 \%$ of solid waste production (Tessitore et al., 2014). The cumulative negative impacts of SMTEs operation on the marine environment are substantial compared to resorts (Hamzah \& Hampton, 2013; Kasim \& Dzakiria, 2009). Many works of the literature suggested that SMTEs should engage in environmental management practices due to their cumulative negative impacts (Sampaio, Thomas, \& Font, 2012). However, SMTEs engagement in green operation practices is low, which is acknowledged by various studies (Hellmeister \& Richins, 2019; Jamaludin \& Yusof, 2016). These studies only mentioned that SMTEs have low performance due to various barriers but do not provide statistical evidence of the performance level. Limited studies are available that determine SMTEs green operation practices performance levels statistically in the marine environment. Furthermore, similar studies conducted in the Malaysian context are not available.

\subsection{Purpose and objectives of the study}

This study investigates the SMTEs green operation practices performance index in the area of energy, freshwater, and solid waste. It is anticipated that the study's outcome will help SMTEs operators improve their green operation practices and the quality of life of islanders.

eISSN: 2398-4287@ 2021. The Authors. Published for AMER ABRA cE-Bs by e-International Publishing House, Ltd., UK. This is an open access article under the CC BYNC-ND license (http://creativecommons.org/licenses/by-nc-nd/4.0/). Peer-review under responsibility of AMER (Association of Malaysian Environment-Behaviour Researchers), ABRA (Association of Behavioural Researchers on Asians/Africans/Arabians) and cE-Bs (Centre for Environment-Behaviour Studies), Faculty of Architecture, Planning \& Surveying, Universiti Teknologi MARA, Malaysia.

DOI: https://doi.org/10.21834/ebpj.v6i16.2729 
The objectives are to identify the operators' social characteristics, determine the green operation practices in the area of energy, freshwater, and solid waste, and to analyse the performance levels of SMTEs green operation practices.

\subsection{Literature Review}

Malaysia is a rich country with marine biodiversity assets such as colorful coral reefs and marine fishes. Marine beauty has attracted high numbers of locals and international tourists. Overdevelopment of the SMTEs on the islands causes severe degradation of marine ecological assets. Improper operations of SMTEs are causing cumulative adverse impacts on the island's flora, fauna, water, and air quality (Asadi et al., 2020). Many literature works suggested that Malaysian SMTEs operators should engage in environmental management practices due to their cumulative negative impacts (Deraman et al., 2017). Moreover, SMTEs engagement in green operation practices worldwide is low due to various barriers (Jamaludin \& Yusof, 2016; Teruel-Gutiérrez, 2020). However, many studies were conducted on green operation practices of hotels and resorts at Malaysia marine islands (Yusof \& Jamaludin, 2015; Ashourian et al., 2013). Conversely, studies regarding the performance level of green operation practices of Malaysian SMTEs remain limited (Hamzah \& Hampton, 2013; Kasim, 2009). Therefore, this study was conducted.

\subsection{Areas of green operation practices}

Analysis of numerous studies indicates three primary areas of green operation practices: energy, water, and solid waste management (Kim, Lee, \& Fairhurst, 2017, Beryl Omune, 2021). However, there are other areas such as community involvement, pollution prevention, indoor air quality control, noise reduction, green product purchasing, green transportation, environmental education, human resource development, environmental policy, toxic waste management, sustainable site operation, and many more. This study only focused on the three primary areas namely energy, freshwater and solid waste. Analysis of the green operation practices studies indicates that green operation practices are classified into low-cost or high-tech approaches. The low-cost green practice applies minimal implementation and maintenance cost but can save up to $20 \%$ of the total expenditure (Rahman et al., 2012). It pertains more towards behavioral activities such as waste recycling, linen reuse program, switching off lights when leaving rooms, etc. The high-tech green practices incur high implementation and maintenance costs, but the investment return is fast: solar technology, automatic water faucets, lighting sensors, occupancy sensors, and much more. This study focused on the low-cost type of green operation practices due to the characteristics of SMTEs as heterogeneous in nature, small in size, limited capital, and operate by a single owner (Hillary, 2004).

\subsection{Methodology}

\subsection{Study Area}

This study was conducted on the four Marine Park Islands (MPIs) in Peninsular Malaysia: Redang, Perhentian, Kapas, and Tioman Island.

\subsection{Identification of green operation measures}

Analyses of literature and pilot study at the Perhentian and Tioman Island have indicated nine appropriate green measures for energy, water, and solid waste management (Table 1).

Table 1. List of green measures for energy, freshwater and solid waste management

\begin{tabular}{|c|c|c|}
\hline Energy Measures & Freshwater Measures & Solid Waste Measures \\
\hline Use of solar energy as supporting energy system. & $\begin{array}{l}\text { Checking water faucets and taps to prevent } \\
\text { wastages. }\end{array}$ & $\begin{array}{l}\text { Positioned several recycling bins within chalet } \\
\text { area. }\end{array}$ \\
\hline Use outdoor solar lighting. & Use of water efficient fixtures such as aerators. & Waste separation \\
\hline $\begin{array}{l}\text { Guests are advised to save energy during their } \\
\text { stay. }\end{array}$ & Use of dual flush water closets & Recycle leftover cooking oil for other purposes. \\
\hline Monitoring of energy based on the energy record. & Set limits on the extraction of ground or hill water & Creatively reuse unwanted natural material. \\
\hline Use of energy efficient light bulbs. & $\begin{array}{l}\text { Watering surrounding plants early morning or late } \\
\text { evening }\end{array}$ & Buy goods in bulk to reduce packaging. \\
\hline Use of energy saving appliances. & Use rainwater in the operation & Provide drinking water in a dispenser \\
\hline Linens are dry sun dried. & Monitoring of water bill to avoid leakages. & Serve foods using permanent kitchenware. \\
\hline $\begin{array}{l}\text { Switch off all the electrical equipment when not in } \\
\text { use. }\end{array}$ & Reminding guests about saving water. & Refill shampoo in the dispenser. \\
\hline Air-conditioners set to higher temperature & Maintenance of water pumps and water tanks. & Composting of dry and wet waste \\
\hline
\end{tabular}

\subsection{Data collection}

This study applied the questionnaire and interview method. Out of 115 chalets operators on the four MPIs, 93 haves responded to the self-administered questionnaire survey. With a response rate of $80.9 \%$, it is sufficient for further analysis (Krejcie \& Morgan, 1970). The first part of the questionnaire asks about the operators' social characteristics while the second part is focused on operators' green operation practices. The questionnaire was designed based on the Brown (2010) study using a Likert of 0: Not applicable, 1: Never, 2 : Rarely 3: Sometimes, 4: Very often, and 5: Always. From each island, three operators were selected for in-depth interviews. The 
operators were interviewed using a semi-structured questionnaire. The findings from the interviews supported the findings from the questionnaires.

\subsection{Statistical analysis}

The reliability test was carried out to determine the internal consistency of the 27 green measures (Tabachnick \& Fidell, 2014). Overall, Cronbach's alpha value for the measures was 0.902 , and all measures have scored more than 0.70 . Therefore, all the measures are retained for further analysis. The objectives of the study are answered using descriptive analysis. The mean of each green measure is summed up to obtain the Total Mean. The group mean for each area is also calculated. The group mean indicates which island has the highest or lowest performance in the selected area. Finally, the performance index is calculated by averaging the three group's mean scores (Table 7). As for reporting, the Likert scales are changed to performance scale and mean range (Table 2). The purpose was to simplify the reporting of the performance level. The method was adopted by referring to two studies (Erdogan \& Tosun, 2009; Lewis \& Cassells, 2010).

Table 2. Frequency Likert Scale Changed to Performance Level Likert Scale and Mean Range

\begin{tabular}{lll}
\hline Frequency Likert scale & Performance level & Mean range \\
\hline 0= Not applicable & Not applicable & 0.00 \\
\hline 1= Never & No performance & $1.00-1.22$ \\
\hline 2= Rarely & Low performance & $1.23-2.48$ \\
\hline 3= Sometime & Moderate performance & $2.49-3.74$ \\
\hline 4= Very Often & High performance & $3.75-5.00$ \\
5= Always & \\
\hline
\end{tabular}

\subsection{Limitation of the study}

The limitations associated with the study are only four islands were chosen because of limited time and cost. Second, only small and medium types of chalets are studied. Third, only three operators were interviewed from each island due to time limitations.

\subsection{Findings}

\subsection{Social Characteristics of the operators}

Findings in Table 3 indicate that 74 operators were male (79.6\%) and 19 operators were female (20.4\%). The operators' age profile revealed that the age range from 45 to 54 years was the highest (36.6\%) while 65 years and above was the lowest $(2.2 \%)$. As from the working position, 48 operators are managers (51.6\%), and 45 are owners and managers (48.4\%). As regards ethnicity, 81 operators are Malay ( $87.1 \%)$, followed by five operators who are Chinese $(5.4 \%)$, two operators are Indian (2.2\%), and five operators are foreigners $(5.4 \%)$. The foreign operators are from UK and Netherlands. As regards formal education level, 65 operators have a secondary education level (69.9\%), while 24 operators have a higher education level (25.9\%), and four operators have a primary education level (4.3\%).

Table 3. Demographic profiles of the SMTEs operators

\begin{tabular}{|c|c|c|c|}
\hline DIMENSION & MEASURES & FREQUENCY & PERCENTAGE \\
\hline \multicolumn{4}{|c|}{ Part 1A: Respondent Profile } \\
\hline \multirow[t]{2}{*}{ Gender } & Male & 74 & $79.6 \%$ \\
\hline & Female & 19 & $20.4 \%$ \\
\hline \multirow[t]{7}{*}{ Age } & Below 21 & - & - \\
\hline & $21-24$ & - & - \\
\hline & $25-34$ & 12 & $12.9 \%$ \\
\hline & $35-44$ & 22 & $23.7 \%$ \\
\hline & $45-54$ & 34 & $36.6 \%$ \\
\hline & $55-64$ & 23 & $24.7 \%$ \\
\hline & 65 or above & 2 & $2.2 \%$ \\
\hline \multirow[t]{2}{*}{ Position } & Manager & 48 & $51.6 \%$ \\
\hline & Owner and manager & 45 & $48.4 \%$ \\
\hline \multirow[t]{4}{*}{ Ethnicity } & Malay & 81 & $87.1 \%$ \\
\hline & Chinese & 5 & $5.4 \%$ \\
\hline & Indian & 2 & $2.2 \%$ \\
\hline & Others & 5 & $5.4 \%$ \\
\hline \multirow{7}{*}{$\begin{array}{l}\text { Educational } \\
\text { qualification }\end{array}$} & Primary & 4 & $4.3 \%$ \\
\hline & Secondary & 65 & $69.9 \%$ \\
\hline & Certificate & 4 & $4.3 \%$ \\
\hline & Diploma & 1 & $1.1 \%$ \\
\hline & Degree & 18 & $19.4 \%$ \\
\hline & Master & - & - \\
\hline & PhD & 1 & $1.1 \%$ \\
\hline
\end{tabular}




\subsection{Performance level in the area of energy}

Green operation practices' performance level in the energy area was measured according to the nine measures shown in Table 4. The table indicates that most of the operators are highly performing the three measures because the measures are easy to perform and reduce operating costs. The measures are linens sundry (4.67), all the electrical equipment switched off when not in use (4.52), and guests advised to save energy during their stay (4.05).

Table 4. Energy management practices on the case studies islands.

\begin{tabular}{|c|c|c|c|c|c|c|}
\hline \multirow[t]{2}{*}{ NO } & \multirow[t]{2}{*}{ INDICATOR AND MEASURES } & \multicolumn{4}{|c|}{ MEAN } & \multirow{2}{*}{$\begin{array}{l}\text { TOTAL } \\
\text { MEAN }\end{array}$} \\
\hline & & Tioman & Kapas & Redang & Perhentian & \\
\hline \multicolumn{7}{|c|}{ ENERGY MANAGEMENT } \\
\hline 1. & Use of solar energy as supporting energy system. & 1.00 & 1.00 & 1.80 & 1.27 & 1.27 \\
\hline 2. & Use outdoor solar lighting. & 1.00 & 1.00 & 1.00 & 1.00 & 1.00 \\
\hline 3. & Guests are advised to save energy during their stay. & 4.50 & 4.63 & 3.53 & 3.53 & 4.05 \\
\hline 4. & Monitoring of energy based on the energy record. & 3.00 & 4.13 & 0.00 & 0.00 & 1.78 \\
\hline 5. & Use of energy efficient light bulbs. & 2.51 & 4.25 & 4.00 & 2.77 & 3.38 \\
\hline 6. & Use of energy saving appliances. & 1.51 & 1.80 & 1.30 & 1.80 & 1.60 \\
\hline 7. & Linens are dry sun dried. & 4.87 & 5.00 & 4.70 & 4.10 & 4.67 \\
\hline 8. & Switch off all the electrical equipment when not in use. & 4.82 & 4.75 & 5.00 & 3.50 & 4.52 \\
\hline \multirow[t]{2}{*}{9.} & $\begin{array}{l}\text { Air-conditioners set to higher temperature such as } 24 \\
\text { degrees Celsius. }\end{array}$ & 0.93 & 0.63 & 1.00 & 0.93 & 0.87 \\
\hline & Group mean & 2.68 & 3.02 & 2.48 & 2.10 & 2.57 \\
\hline
\end{tabular}

$0.00=$ Not applicable, 1.00-1.22=No performance, 1.23-2.48=Low performance, 2.49-3.74=Moderate performance, 3.75-5.00=High performance.

The results also indicate that the operators are moderately performing one measure due to the high cost regarding energy-saving measures. The measure is the use of energy-efficient light bulbs (3.38). The findings also indicate that three measures were recorded with low performance for a similar reason. The measures are the use of solar energy as supporting energy systems (1.27), monitoring of electricity based on the electric bill (1.78), and use of energy-saving equipment (1.60). The solar energy system is new to the operators, which requires a high implementation cost. Regarding monitoring energy based on the energy bill, only Tioman and Kapas operators performed it because they received electricity from the island power station. However, Kapas operators performed the measure more frequently (4.13) than Tioman operators (3.00) because their solar energy bill from the central power station is more expensive than private diesel generator bill.

Regarding energy-saving equipment (1.60), all the operators stated that energy-saving equipment is more expensive than conventional equipment. Moreover, energy-saving equipment is not suitable to use when diesel generators in use. The equipment is easily damaged. For example, most operators stated that their energy-saving bulbs, air-conditioners, and TVs frequently blow up due to the unstable electricity from the diesel generators.

One measure that all the operators do not perform is solar lighting for outdoor areas (1.00). Most of the operators stated they are unaware of outdoor solar lighting and where to buy it. One measure was not applicable for the operators. The measure is setting airconditioners to the higher thermostat ( 0.87$)$. Most of the operators are not performing the measure because they found that the measure is not applicable. After all, chalets are hot during the daytime. Therefore, adjusting air-conditioners to the higher thermostat is not practical on the islands.

\subsection{Performance level in the area of freshwater management}

Green operation practices' performance level in freshwater management are measured according to the nine measures shown in Table 5. Overall, the table indicates that most operators are highly performing two measures. The measures are to check water faucets and taps to prevent water wastages (4.05) and reminding guests about saving water (3.79). Regarding checking water faucets and fixtures, the measure was highly performed by Redang (4.30) and Kapas operators (4.25). The operators stated that the measure is performed because there is no additional cost and easy to perform.

Table 5. Freshwater management practices on the case studies islands

\begin{tabular}{|c|c|c|c|c|c|c|}
\hline \multirow[t]{2}{*}{ NO } & \multirow[t]{2}{*}{ INDICATOR AND MEASURES } & \multicolumn{4}{|c|}{ MEAN } & \multirow{2}{*}{$\begin{array}{l}\text { TOTAL } \\
\text { MEAN }\end{array}$} \\
\hline & & Tioman & Kapas & Redang & Perhentian & \\
\hline \multicolumn{7}{|c|}{ FRESHWATER MANAGEMENT } \\
\hline 1. & Checking water faucets and taps to prevent wastages. & 3.96 & 4.25 & 4.30 & 3.70 & 4.05 \\
\hline 2. & Use of water efficient fixtures such as aerators. & 1.47 & 1.13 & 2.00 & 1.63 & 1.56 \\
\hline 3. & Use of dual flush water closets & 1.11 & 1.25 & 1.60 & 1.57 & 1.38 \\
\hline 4. & Set limits on the extraction of ground or hill water & 1.09 & 1.00 & 1.11 & 1.15 & 1.36 \\
\hline 5. & $\begin{array}{l}\text { Watering surrounding plants early morning or late } \\
\text { evening }\end{array}$ & 2.90 & 2.38 & 3.24 & 2.37 & 2.72 \\
\hline 6. & Use rainwater in the operation & 1.00 & 1.00 & 1.00 & 1.00 & 1.00 \\
\hline 7. & Monitoring of water bill to avoid leakages. & 0.50 & 0.00 & 0.00 & 0.78 & 0.32 \\
\hline 8. & Reminding guests about saving water. & 3.40 & 4.13 & 4.40 & 3.23 & 3.79 \\
\hline \multirow[t]{2}{*}{9.} & Maintenance of water pumps and water tanks. & 2.67 & 2.63 & 2.60 & 2.20 & 2.53 \\
\hline & Group Mean & 2.04 & 2.00 & 2.32 & 2.01 & 2.07 \\
\hline
\end{tabular}


Meanwhile, in terms of reminding guests to save water, only the operators who have water shortages during peak seasons remind their guests to save water. For example, Redang (4.40) and Kapas operators (4.13) were highly performing the measure because their operation depends on the groundwater. After all, stream or hill water dries up quickly during the dry season. The findings also indicate that two measures are moderately performed. The measures are maintenance of water tanks and pumps (2.53) and watering of surrounding plants early morning or late evening (2.72).

The results also indicate that three measures have low performance. The measures are the use of water-efficient fixtures such as aerators (1.56), the use of dual-flush water closets (1.38), and set limits on the extraction of ground or hill water (1.36). Some operators stated they do not know about aerators and dual-flush water closets function. Five operators informed that the dual-flush water closet is inefficient because it is prone to malfunction due to push buttons systems.

Most of the operators do not set any target limits regarding limiting the groundwater or hill water extraction because peak season occurred during dry seasons. Consequently, the majority of the operators are pumping groundwater continuously. All operators do not perform one measure, which is using rainwater in operation (1.00). Some operators never thought of collecting rainwater, while others said they do not have sufficient knowledge regarding the system.

\subsection{Performance level in the area of solid waste management}

Green operation practices' performance level of solid waste management was measured according to the nine measures shown in Table 6. The findings illustrate that the operators highly performed two recycling measures. The measures were to serve foods in permanent kitchenware (5.00) and buy goods in bulk to reduce packaging (4.08). As for both measures, the operators want to minimize the cost and amount of waste produce. The table also indicates that four measures moderately performed.

Table 6. Solid waste management practices on the case studies islands

\begin{tabular}{|c|c|c|c|c|c|c|}
\hline \multirow[t]{2}{*}{ NO } & \multirow[t]{2}{*}{ INDICATOR AND MEASURES } & \multicolumn{4}{|c|}{ MEAN } & \multirow{2}{*}{$\begin{array}{l}\text { TOTAL } \\
\text { MEAN }\end{array}$} \\
\hline & & Tioman & Kapas & Redang & Perhentian & \\
\hline \multicolumn{7}{|c|}{ SOLID WASTE MANAGEMENT } \\
\hline 1. & Positioned several recycling bins within chalet area. & 2.20 & 1.63 & 2.90 & 1.13 & 1.97 \\
\hline 2. & $\begin{array}{l}\text { Waste separation such as plastics bottles, } \\
\text { aluminum cans, glass bottles }\end{array}$ & 3.69 & 2.75 & 4.50 & 2.07 & 3.25 \\
\hline 3. & Recycle leftover cooking oil for other purposes. & 2.60 & 3.88 & 3.80 & 2.03 & 3.08 \\
\hline 4. & Creatively reuse unwanted natural material. & 2.20 & 3.25 & 2.76 & 2.20 & 2.60 \\
\hline 5. & Buy goods in bulk to reduce packaging. & 4.13 & 3.50 & 5.00 & 3.70 & 4.08 \\
\hline 6. & Provide drinking water in a dispenser & 2.62 & 2.50 & 4.40 & 2.20 & 2.93 \\
\hline 7. & Serve foods using permanent kitchenware. & 5.00 & 5.00 & 5.00 & 5.00 & 5.00 \\
\hline 8. & Refill shampoo in the dispenser. & 0.00 & 0.00 & 0.00 & 0.00 & 0.00 \\
\hline \multirow[t]{2}{*}{9.} & Composting of dry and wet waste & 1.50 & 1.18 & 1.00 & 1.18 & 1.22 \\
\hline & Group Mean & 2.66 & 2.63 & 3.26 & 2.17 & 2.68 \\
\hline
\end{tabular}

The measures were waste separation (3.25), recycling leftover cooking oil (3.08), provide water in the drinking dispenser to reduce plastic bottles (2.93), and creatively reuse the unwanted things (2.60). Concerning waste separation, Redang operators highly perform the measure (4.50) due to upscale accommodations. Meanwhile, other island operators have low performance due to unavailable service of picking recycling waste.

Regarding creatively reusing the natural things for other purposes, the result indicates that Kapas operators are more creative than other island operators (3.25). Some examples were fishing nets used as hammocks, boat ropes as garden decorations, glass and plastic bottles as decoration, and many more. The findings also indicate that one measure recorded low performance. The measure is positioning the recycling bins within the chalets compound (1.97). Most of the operators are less performing the measure because of the high cost of a recycling bin. One measure was identified as not being applicable. All operators do not provide shampoo dispensers in the bathroom because they cannot offer toiletries for guests. Lastly, one measure has no performance. The measure is composting of wet and dry waste (1.22). The majority of the operators are not performing the measure because of a lack of time, staff, and knowledge.

\subsection{Discussion}

\subsection{Social characteristic of the operators}

Overall, the findings indicate the majority of the operators are male. Male usually operate the hospitality business because it reflects Malaysia's local culture where males are the front-runners of businesses. The survey also identified that most of the operators are in the late 40s, typical in the hospitality business (Abdullah, Ishak \& Farah, 2012). The result also indicates that most operators with low education level have little knowledge and interest in green operation practices (Hillary, 2004).

\subsection{Area of green operation practices}


Analysis from the findings identified that most operators adopted low-cost green operation practices in energy, freshwater, and solid waste. The main factor is to reduce the operating costs. However, there are other reasons such as high competitiveness among operators to improve the quality of services, deterioration of the marine environment, external public pressure and high environmental consciousness. This finding is consistent with the previous studies (Walker et al., 2008; Graci \& Dodds., 2008).

\subsection{Green operation performance level}

Performance Index in Table 7 indicates that most SMTEs at the islands have a low performance of green operation practices in energy, freshwater, and solid waste (2.45). This finding consistent with other studies (Walker et al., 2008; Kasim \& Dzakiria, 2009). However, individually solid waste (2.68) and energy management (2.57) have moderate performance compared to freshwater management (2.07). Freshwater management has the lowest performance due to most operators extracting groundwater or hill water, which is free. Therefore, they do not see the importance of performing water-saving practices in their operation.

Table 7. Summary of the green operation performance level

\begin{tabular}{|c|c|c|c|c|c|c|}
\hline \multirow[t]{2}{*}{ GREEN INDICATORS } & \multicolumn{4}{|c|}{ GROUP MEAN } & \multirow{2}{*}{$\begin{array}{l}\text { TOTAL } \\
\text { MEAN }\end{array}$} & \multirow{2}{*}{$\begin{array}{l}\text { Performance } \\
\text { Index }\end{array}$} \\
\hline & Tioman & Kapas & Redang & Perhentian & & \\
\hline $\begin{array}{l}\text { Solid waste } \\
\text { management }\end{array}$ & 2.66 & 2.63 & 3.26 & 2.17 & 2.68 & Moderate \\
\hline $\begin{array}{l}\text { Freshwater } \\
\text { management }\end{array}$ & 2.04 & 2.00 & 2.32 & 2.01 & 2.07 & Low \\
\hline Energy management & 2.68 & 3.02 & 2.48 & 2.10 & 2.57 & Moderate \\
\hline $\begin{array}{l}\text { Performance Index } \\
\text { (Mean) }\end{array}$ & 2.46 & 2.55 & 2.69 & 2.09 & 2.45 & Low \\
\hline
\end{tabular}

3.75-5.00=High performance

\subsection{Conclusion and recommendations}

Overall, the results indicated a low performance of green operation practices in energy, freshwater, and solid waste. The reasons are high implementation and maintenance costs, lack of staff, time, motivation, environmental awareness, low education level, no interest, high transportation cost, and lack of knowledge. Therefore, several appropriate recommendations are listed below:

- Operators should have proper schedules for staff to conduct green operation practices.

- Operators should have green policies and clear strategies for their operations.

- Operators should attend various seminars, workshops, and discussions to increase awareness and knowledge

- Operators should think creatively how to reduce waste, water, and energy.

- Operators should hire sufficient number of staff to perform green operation practices.

- Operators should seek expert advice regarding green operation practices.

- Operators need to seek monetary help from the government to improve their green operation.

This information may help the SMTEs operators to increase their green operation practices performance level. This research can continue to other Islands in Peninsular Malaysia to identify the green operation practices performance index and formulate an appropriate recommendation for the island's management.

\section{Acknowledgments}

This research grant fund by MOHE under the FRGS RACER 2019-1 Grant (RACER/1/2019/SSI11/UIAM/11)

\section{Paper Contribution to Related Field of Study}

This study has contributed knowledge in the area of green operation practices for SMTEs and sustainable marine tourism.

\section{References}

Abdullah, F. Z., Ishak, N. K., \& Farah, L. B. (2012). A case study of small budget chalets at East Coast of Malaysia. International Journal of Business and Social Science, 3(1).

Ashourian, M. H., Cherati, S. M., Zin, A. M., Niknam, N., Mokhtar, A. S., \& Anwari, M. (2013). Optimal green energy management for island resorts in Malaysia. Renewable energy, 51, 36-45.

Asadi, S., Pourhashemi, S. O., Nilashi, M., Abdullah, R., Samad, S., Yadegaridehkordi, E., \& Razali, N. S. (2020). Investigating influence of green innovation on sustainability performance: A case on Malaysian hotel industry. Journal of cleaner production, 258, 120860. 
Beryl Omune, Oscar Kambona, Billy Wadongo \& Amon Wekesa (2021) Environmental management practices implemented by the hotel sector in Kenya, World Leisure Journal, DOI: $10.1080 / 16078055.2021 .1888001$

Brown, A. P. (2010). Qualitative method and compromise in applied social research. Qualitative research, 10(2), 229-248.

Chan, E. S., \& Hsu, C. H. (2016). Environmental management research in hospitality. International Journal of Contemporary Hospitality Management.

Deraman, F., Ismail, N., Mod Arifin, A. I., \& Mostafa, M. I. A. (2017). Green practices in hotel industry: Factors influencing the implementation. Journal of Tourism, Hospitality \& Culinary Arts (JTHCA), 9(2), 1-12.

Erdogan, N., \& Tosun, C. (2009). Environmental performance of tourism accommodations in the protected areas: Case of Goreme Historical National Park. International journal of hospitality management, $28(3), 406-414$

Graci, S., \& Dodds, R. (2008). Why go green? The business case for environmental commitment in the Canadian hotel industry. Anatolia, 19(2), 251-270.

Hamzah, A., \& Hampton, M. P. (2013). Resilience and non-linear change in island tourism. Tourism Geographies, 15(1), 43-67.

Hellmeister, A., \& Richins, H. (2019). Green to Gold: Beneficial Impacts of Sustainability Certification and Practice on Tour Enterprise Performance. Sustainability, 11(3), 709.

Hillary, R. (2004). Environmental management systems and the smaller enterprise. Journal of cleaner production, 12(6), 561-569.

Jamaludin, M., \& Yusof, Z. B. (2016). Barriers of Adopting Environmental Management Practices in the Micro and Small Island Chalets Operation. EnvironmentBehaviour Proceedings Journal, 1(1), 171-177.

Kasim, A., \& Dzakiria, H. (2009). Encouraging environmental management among small and medium accommodations (SMAs) through e-learning initiative. Turkish Online Journal of Distance Education, 10(2), 162-174.

Kim, S. H., Lee, K., \& Fairhurst, A. (2017). The review of "green" research in hospitality, 2000-2014. International Journal of Contemporary Hospitality Management. Mejia, C. (2019). Influencing green technology use behavior in the hospitality industry and the role of the "green champion". Journal of Hospitality Marketing \& Management, 28(5), 538-557.

Krejcie, R. V., \& Morgan, D. W. (1970). Determining sample size for research activities. Educational and psychological measurement, 30(3), 607-610.

Lewis, K., \& Cassells, S. (2010). Barriers and drivers for environmental practice uptake in SMEs: A New Zealand perspective. International Journal of Business Studies: A Publication of the Faculty of Business Administration, Edith Cowan University, 18(1), 7-21.

Mejia, C. (2019). Influencing green technology use behavior in the hospitality industry and the role of the "green champion". Journal of Hospitality Marketing \& Management, 28(5), 538-557.

Persic-Zivadinov, Irena, Mrsc; Blazevic, Branko.(2010). Sustainable hotels: sustainable life cycle practice in Croatian hotels. In Faculty of Tourism and Hospitality Management in Opatija. Biennial International Congress. Tourism \& Hospitality Industry (p. 161). University of Rijeka, Faculty of Tourism \& Hospitality Management.

Rahman, I., Reynolds, D., \& Svaren, S. (2012). How "green" are North American hotels? An exploration of low-cost adoption practices. International journal of hospitality management, 31(3), 720-727.

Sampaio, A. R., Thomas, R., \& Font, X. (2012). Small business management and environmental engagement. Journal of Sustainable Tourism, 20(2), 179-193. Fernández-Robin, C., Celemín-Pedroche, M. S., Santander-Astorga, P., \& Alonso-Almeida, M. D. M. (2019). Green practices in hospitality: A contingency approach. Sustainability, 11(13), 3737.

Tabachnick, B. G., \& Fidell, L. S. (2014). Using multivariate statistics: Pearson new international edition. Pearson.

Teruel-Gutiérrez, R. (2020). Sustainability as a corporate strategy: A performance comparison of green and non-green SME Hotels. Small Business International Review, 4(2), 30-38

Tessitore, S., Testa, F., Daddi, t., \& Iraldo, F. (2014). the cluster approach as a solution to improve environmental management at smes level: a comparison study. environmental engineering \& management journal (eemj), 13(7).

Walker, B., Redmond, J., Sheridan, L., Wang, C., \& Goeft, U. (2008). Small and medium enterprises and the environment: barriers, drivers, innovation and best practice: A review of the literature.

Yusof, Z. B. B., \& Jamaludin, M. (2015). Green Practices of Small Island Chalet Operators in East Peninsular Malaysia. Procedia-Social and Behavioral Sciences, 202, $340-350$ 